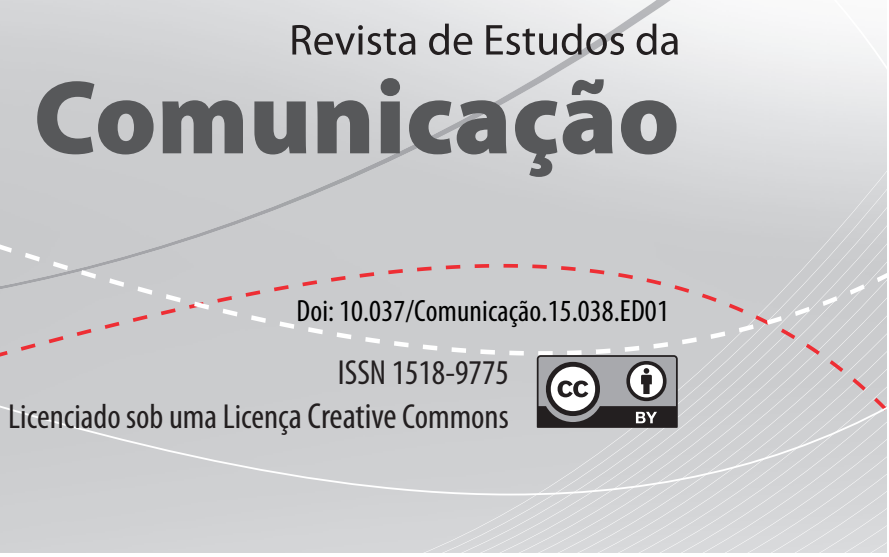

\title{
Editorial
}

\section{Comunicação digital e a convergência da pesquisa}

Esta edição especial da Revista de Estudos da Comunicação tenta refletir como o digital permeia os diferentes ramos da pesquisa em comunicação. Assim, realizou-se uma seleção de artigos que formam um mosaico de tendências nacionais e internacionais de estudos relacionados à Comunicação Digital, tema a que identifica este fascículo especial.

Afastando-se um pouco da sua tradição de aguardar submissões de resenhas e artigos, a Revista entrou em contato direto com os líderes dos Grupos de Pesquisa do Intercom e solicitou que detectassem trabalhos apresentados no XXXVII Congresso Brasileiro de Ciências da Comunicação, realizado em setembro, em Foz do Iguaçu, e convidassem seus autores a submetê-los em regime especial, uma vez que estavam previamente aprovados pelos pareceristas do evento. Desta forma, a Revista de Estudos da Comunicação, excepcionalmente, os submeteu a apenas um parecerista e procedeu as revisões e processos internos de praxe. Normalmente, a avaliação é feita pelo editor-chefe e por pares de avaliadores doutores pesquisadores na área relacionada ao tema do artigo. Concomitantemente, houve divulgação normal, resultando em várias outras submissões, estas encaminhadas ao processo regular de avaliação. O resultado, como o leitor poderá constatar, foi bastante positivo: a proposta de revelar tendências das pesquisas em Co- 
municação Digital e de demonstrar que o digital permeia as mais diversas correntes foi alcançada.

A edição abre com o artigo "El flow se estanca", de Jaime Costas Nicolás, da Universidad Pompeu Fabra (Barcelona), que aborda a nova linguagem das séries sitcom, tradicionalmente televisivas, mas que adaptam sua linguagem à rede, na qual o expectador liberta-se das imposições de horários e dos intervalos comerciais e conquista papel ativo, com poder de interferir até no enredo. O segundo artigo, por sua vez, remete a uma das regiões economicamente mais pobres do Brasil, porém, culturalmente rica, onde o curso de Jornalismo da Universidade Federal de Minas Gerais realiza oficinas com jovens, que resultam em podcasts publicados livremente na rede e também organizados em um programa veiculado pela Rádio Educativa da UFMG. Os resultados, que passam pelo empoderamento do jovem da região, valorização da cultura regional e pelo evidenciar de novas linguagens comunicacionais, foram relatados e analisados por Graziela Valadares Gomes de Mello Vianna, da UFMG, no artigo "Vozes do Vale: usos do podcast por jovens do Vale do Jequitinhonha".

As evoluções tecnológicas, notadamente nas duas últimas décadas, têm transformado significativamente as formas de produção e veiculação do jornalismo ao ponto de estarem, atualmente, concorrendo com o trabalho do jornalista. Tanto é verdade que o artigo "Textos gerados por softwares - surge um novo gênero jornalístico?", de Márcio Carneiro de Santos, da Universidade Federal do Maranhão, teoriza e relata pesquisa empírica de construção de textos por aplicativos que coletam dados da Internet e os transformam em lides jornalísticos. Já o trabalho "O controle do que dizemos na rede visto pelas políticas do Google", de Lícia Frezza Pisa, do Centro Universitário de Franca, toma como base as noções de discurso e poder de Foucault para analisar o mecanismo de busca Google e concluir que ele não condiz com a imagem democrática e livre da Internet.

Na sequência, o artigo "A Rede de Oposição Radical no Facebook", de autoria de Manoel dos Santos, da Universidade Federal Fluminense, vale-se da construção de grafos com auxílio de softwares para proceder a uma análise das redes sociais de oposição que se estabeleceram no Facebook durante a campanha eleitoral para a Presidência da República em 2014. Assim, evidencia as relações entre grupos e mostra de forma bastante interessante o vazio dos discursos e a difusão de chavões e frases de impacto.

A inclusão digital, tratada no artigo sobre os jovens do Vale do Jequitinhonha, volta à pauta em outro trabalho no qual fica evidente que apesar dos percentuais de lares com acesso à Internet superarem os $50 \%$ e do número de linhas de celulares ser maior que o de brasileiros, o país, assim como em outros índices sociais, apresenta grande variação em relação ao acesso à comunicação digital quando se analisa o tema sob a ótica regional, estratificação social, idade ou ubi- 
cação urbana e rural. Esta realidade, conforme análise de Elen Cristine Geraldes em parceria com Vanessa Negrini, ambas da Universidade Nacional de Brasília, no artigo "Políticas públicas de comunicação e inclusão digital", exclui significativa parcela da população da esfera pública da Internet e revela a necessidade de ações governamentais reversivas à situação.

As transformações na indústria cultural devido à rede mundial de computadores também se faz presente nesta edição com o artigo "Abordagens conceituais sobre o cenário midiático contemporâneo: das indústrias culturais às redes digitais". O estudo, elaborado por Dostoiewski Mariatt de Oliveira Champangnatte e Marcus Alexandre de Pádua Cavalcanti, da Unigranrio, traz à tona as possibilidades de processos comunicacionais alternativos aos grandes conglomerados nos quais os emissores podem assumir papel de receptores e construir suas próprias plataformas, que convivem com a indústria cultural tradicional.

A edição especial encerra com um trabalho teórico-empírico de Beatriz Bandrão Polivanov, da Universidade Federal Fluminense, intitulado "Fazendo faxina no Facebook: implicações do gerenciamento e comunicação com a rede de contatos para dinâmicas de autoapresentação", o qual aborda a co-construção da autoimagem em função da audiência visível no perfil do sujeito, em paralelo às performances e interações off-line.

Boa leitura e boas pesquisas a todos.

Prof. Dr. Zanei Ramos Barcellos

Editor-chefe 